\title{
Instagram post: Writing caption through process approach in developing writing skill
}

\author{
${ }^{1}$ Mauliya Avivi, ${ }^{\text {Fika Megawati* }}$ \\ ${ }^{1}$ English Language Education Study Program, \\ Faculty of Psychology and Education, \\ Universitas Muhammadiyah Sidoarjo, Indonesia \\ *Corresponding Author \\ Email: fikamegawati@umsida.ac.id
}

\begin{abstract}
Instagram has some features for supporting English learning process. Posting a picture and adding a caption could be a way for developing writing skill. Instagram users are allowed to write caption through process approach that would guide them to make a good writing. This study aims to find out the effect of Instagram caption through process approach on students' writing skill in recount text. Quasi-experimental design was implemented to the two classes of Multimedia students at one of Indonesian vocational high schools. Each class participated in this study consisted of thirty students. The data collection was taken from tests, pre-test and post-test. Then, it was analyzed using Independent $t$-test. The result of this study indicates that Instagram caption through process approach gives positive effect for developing English writing skill. More specifically, the students are able to use their Instagram account as an alternative way to learn English by sharing their experience, strengthen their step in writing skill through editing and revising the draft based on the teacher's feedback, and publish writing product. This study implies that feature in Instagram gives advantages for English teachers and students, and it can be promoted as an attractive educational technology for writing activities.
\end{abstract}

Keywords: Instagram; Process Approach; Writing

$\begin{array}{llll}\text { Received: } & \text { Revised: } & \text { Accepted: } & \text { Published: } \\ \text { 31 May 2020 } & \text { 7 July 2020 } & \text { 28 August 2020 } & \text { 31 August 2020 }\end{array}$

\section{INTRODUCTION}

In this digital era, social media is not only for communication, but it can be defined as a platform for teaching and learning writing. It is supported by Alfiyatun (2018) who explained that the youths are more interested in computer, mobile phone, and internet. Then, the teacher should be able to follow the new teaching style nowadays, and she or he should find several innovative ideas in order to select media that appropriate for teaching and learning process. Ferdig (2007) also mentioned the importance of social media that it is full of interaction with people and interaction in language learning process which is necessary and quite helpful. 
There are several social media such as YouTube, Facebook, Whatsapp, Twitter, Instagram, Snapchat and etc. Nevertheless, not all social media appropriate for learning writing which is recount text because each of them has different features and function. For instance, YouTube, it is one of highly accessed social media nowadays, but it is more suitable for learning listening and speaking than writing recount text. Musonera (2018) found that Instagram has become one of the fastest growing social media in the world. From that statement, Instagram can be applied for learning English writing by using its features.

Using social media or application will cause several negative effects on learning process. One of them is time consuming. This is because the teacher has to ensure that the students have some requirements to access the application. For instance, they should download and have the application, create an account to be able to access, and so on. Consequently, to facilitate teacher and students in the use of social media in learning English, the teacher is able to use several popular social media so that the time consuming does not occur. One of the most popular social media is Instagram.

In accordance with Kessler (2013), Instagram appears as a compatible social media for both teachers and students in connecting, communicating, and sharing information. Anggia (2019) also explained that several features on Instagram can support students to practice their writing. It also allows students to share photos or videos, add captions, use filters, tag others account, and so on. One of them that the students are able to use to practice writing is adding caption on their post. They can use any pictures such as pictures of their holiday or unforgettable moments. Thus, recount text is feasible to be applied as a caption.

However, Sheldon and Bryant (2016) told that Instagram users are still less emphasis to connect with other users and still more on personal identity and self-promotion. To cope with this Triwinarsih (2019) states that the students are able to organize their writing which is using Instagram by adding caption as a way to develop their ability in writing. The use of Instagram in classrooms can help to create a socially connected community of learners. It is gives way for students to communicate and socialize with each other users. Socializing on Instagram is especially done through the like and comment functions, that are not taken for granted by users (Ali, 2014).

Caption is a simple description of the pictures, photos, or videos that posted on Instagram (Alfiyatun, 2018). Caption on Instagram consists of maximum 2200 characters (330 words). On the other hand, besides using Instagram caption for the learning process of recount text, Maharani (2017) mentioned that students should notice in the writing process because it is the important role of writing. Thus, teacher needs appropriate strategies or approaches for students to compose their writing. One of them is process approach.

Tribble (1996) says, process approach is as an approach for teaching writing which stresses in the creativity of the writer. It also notices the development of practicing great writing. According to Adula (2018), implementing the process approach systematically will help students be aware 
that not even the professional writers can get their good writing directly. According to Nabhan (2016), process writing has become a master in English Foreign Language (EFL) writing class.

The process writing approach concerns several steps. Harmer (2004) recommends that there are four steps of process approaches include planning, drafting, editing (reflecting and revising), and final version. In planning step the students have to determine the purpose of writing. Then, they have to think about the language style and the content. In drafting step, the students start to write. They need to focus in developing their ideas and organization. The students check again their draft in editing step. If there are mistakes, they should revise it into correct writing. The last step is final version, the students have completed all of the processes. The result of their writing is ready to be sent or published, and the readers will read their writing outcomes.

Previously, there were several studies about the use of Instagram in writing recount that were conducted by Mursela (2018), Triwinarsih (2019), and Anggia (2019). However, some similarities and differences are found from the previous study and this research. The similarities are the use of recount text as a material, the participants are high school level, and the data collection is using pre-test and post-test. Meanwhile, the most different thing is the researchers used Instagram caption through process approach, and the teacher gave feedback by adding written comments there. Those activities have not been applied before, and it becomes the novelty of this research. Thus, the research question of this present study is formulated as follow: Is there any significant effect of the use of Instagram caption through process approach on students' writing skill in recount text?

\section{METHOD Research design}

In this study, the researchers used quantitative method as the research method. According to Ary \& Razavie (2010), quantitative method is a way to produce the numerical data for answering the research hypothesis. For collecting the data, the researchers used quasi-experimental design that used two classes. The two classes include experimental group and control group. Then, the reason using quasi-experimental design is because the purpose was to reveal the causal relationship between two different groups, and the separation of two groups was not random.

\section{Respondents}

The samples of this study were tenth grade students of Multimedia major at one of vocational schools in Pasuruan Regency, East Java, Indonesia. There are three classes of Multimedia major, but the researchers only used two classes, namely, Multimedia 1 and Multimedia 2 as the sample. Multimedia 2 class as the experimental group which was given a treatment using Instagram caption through process approach, while Multimedia 1 as the control group which was taught by using conventional teaching. Moreover, each class consisted of 30 students. 


\section{Instruments}

Research instrument is a way for collecting the data to make the job easier, and the result received will be preferable, total, and systematic. Then, it will simplify data processing. In addition, Brown (2004) states that test is a method for measuring a person's competence, knowledge, or achievement in a given domain. There are two kinds of instrument which are instrument test and instrument non-test. The researchers used test for the data instrument. The test was given twice including pre-test and post-test.

A pre-test was given to the both of control and experimental class. Pretest was given to know the students' ability and understanding in writing recount text before giving a treatment. On the other hand, a post-test was given to the both of control and experimental group after they got a treatment. In this research, the treatment was given to the experimental group through using Instagram caption through process approach in writing recount text. In addition, the researchers checked the validity and reliability of the test to measure that the test was valid and able to be given to the students.

\section{Procedures}

In this study, for implementing the treatment, Instagram account was created for Multimedia 2 class. It should be set private account which means only the teacher and the students were allowed to access. The privacy setting was used to make it easier for the teacher to provide feedback on the comment feature, and other users who were not members of Multimedia 2 could not post comments. In addition, the researchers used pre-test and post-test to collect the data. Before gaining the test, the researchers asked permission to the school to conduct a research. After getting the permission, the researchers discussed with the English teacher about the purpose, schedule, and two classes that were chosen as the participants of this research. Moreover, the researchers needed two meetings to collect the data. First meeting was used for giving pre-test and doing a half of treatment. Then the second meeting was used for continuing the treatment and giving post-test.

Table 1. Procedure of Collecting Data

\begin{tabular}{|c|c|c|}
\hline 1 & Pre-test & $\begin{array}{l}\text { - The researchers made a research plan before giving the } \\
\text { pre-test to the students. } \\
\text { - Multimedia } 1 \text { class was labelled as the control group that } \\
\text { was taught by using conventional teaching strategy. } \\
\text { - Multimedia } 2 \text { class was labelled as the experimental class } \\
\text { that was taught by using Instagram caption through } \\
\text { process approach. } \\
\text { - Both of classes were given a pre-test to know the students' } \\
\text { capability in English writing before giving a treatment. } \\
\text { - In the pre-test, the students were asked to write a short } \\
\text { paragraph about their unforgettable experience. }\end{array}$ \\
\hline 2 & Treatment & $\begin{array}{l}\text { After giving a pre-test to both of classes, the researchers did } \\
\text { treatment in the experimental group using Instagram caption } \\
\text { through process approach. }\end{array}$ \\
\hline 3 & Post-test & $\begin{array}{l}\text { - After giving a treatment, the control and experimental } \\
\text { group were given a post test. }\end{array}$ \\
\hline
\end{tabular}


During the treatment in the experimental group, process approach in writing was applies as depicted in figure 1.

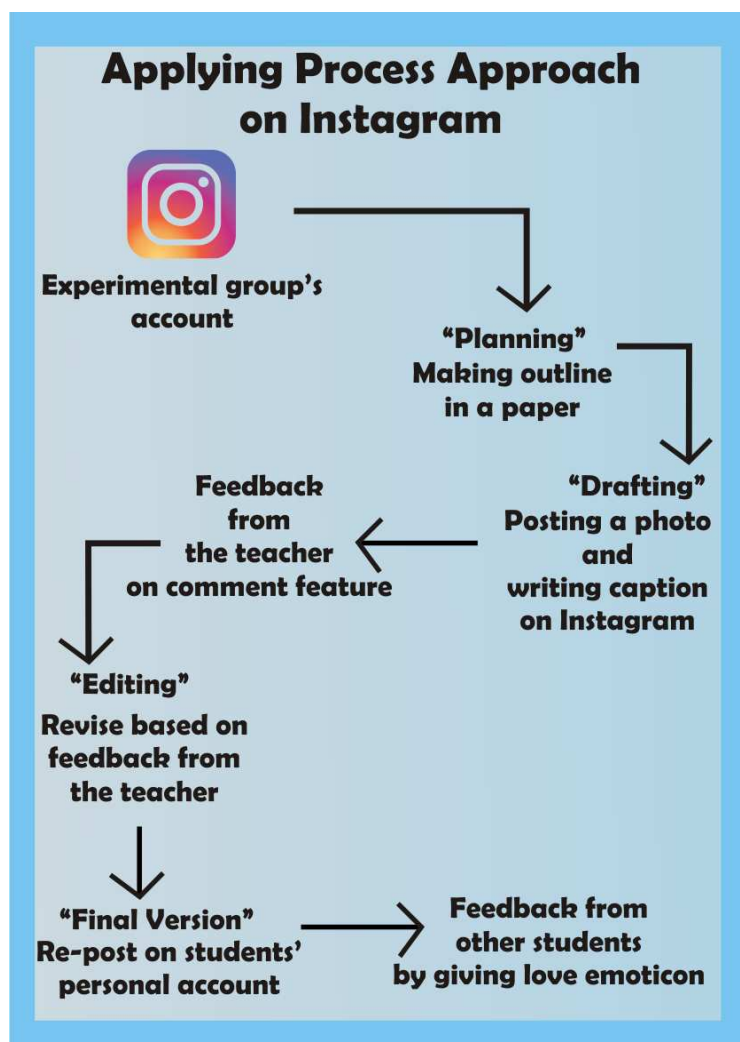

Figure 1. Process approach applied in experimental group

\section{Data analysis}

For analyzing the data, the researchers used statistical calculation using Microsoft Excel. It was calculated after collecting the data of pre-test and posttest. Furthermore, it was used to find out the mean score of pre-test and posttest for both of control and experimental group. The researchers knew the different result of the experimental group which was taught using Instagram caption through process approach and the control group which was not taught using Instagram caption. In addition, the researchers used three stages of analyzing the data which were normality test, homogeneity test, and hypothesis test (independent sample t-test). The independent t-test formula used is in Figure 2.

$$
t=\frac{\overline{x_{1}}-\overline{x_{2}}}{\sqrt{\frac{s_{1}^{2}}{n_{1}}+\frac{s_{2}^{2}}{n_{2}}}}
$$

Figure 2. Independent t-test formula 
Avivi, M., \& Megawati, F. (2020). Instagram post: Writing caption through process approach in developing writing skill. EduLite: Journal of English Education, Literature, and Culture, 5 (2), 240-250. DOI: http://dx.doi.org/10.30659/e.5.2.240-250

Notes:
$\mathrm{s}_{1} \quad:$ the standard deviation of control group
$\mathrm{s}_{2} \quad:$ the standard deviation of experimental group
$\mathrm{x}_{1} \quad$ : the mean score of control group
$\mathrm{x}_{2} \quad$ : the mean score of experimental group
$\mathrm{n}_{1} \quad$ : total students of control group
$\mathrm{n}_{2} \quad$ : total students of experimental group

\section{RESULTS AND DISCUSSION}

The process of learning activities applied in the two classes was different in term of the approach and scenario. It is described in Table 2.

Table 2. Learning Activities of Experimental and Control Class

\begin{tabular}{|c|c|}
\hline \multicolumn{2}{|c|}{ MEETING 1} \\
\hline \multirow{2}{*}{\multicolumn{2}{|c|}{$\begin{array}{l}\text { Experimental Group } \\
\text { - Getting material about recount text }\end{array}$}} \\
\hline & \\
\hline - Showing examples of recount text & $\begin{array}{l}\text { - Showing example of recount text on } \\
\text { Instagram }\end{array}$ \\
\hline $\begin{array}{l}\text { Doing assignments in LKS Bahasa } \\
\text { Inggris kelas } X\end{array}$ & $\begin{array}{l}\text { - Planning (first step) } \\
\text { Making an outline of recount text } \\
\text { - Drafting (second step) } \\
\text { Writing caption of recount on Instagram }\end{array}$ \\
\hline & $\begin{array}{l}\text { Account: @onebee.multimedia } 2 \\
\text { Caption: Students' recount and identities } \\
\text { Features: Location, tagging, comment }\end{array}$ \\
\hline
\end{tabular}

\begin{tabular}{lll}
\hline \multicolumn{1}{c}{ MEETING 2 } \\
\hline Control Group & \multicolumn{1}{c}{ Experimental Group } \\
\hline - Weviewing material of recount text & - $\begin{array}{l}\text { Understanding feedback from teacher in } \\
\text { column feature }\end{array}$ \\
& - $\begin{array}{l}\text { Editing (third step) } \\
\text { Writing revision of recount in a book or } \\
\text { paper }\end{array}$ \\
& - Final Version (fourth step) \\
& Publishing through reposting on personal \\
& Instagram \\
& $\begin{array}{l}\text { Account: Students' personal account } \\
\text { Caption: Students' final recount and identities } \\
\text { Feature: Location, tagging, comment }\end{array}$ \\
\hline
\end{tabular}

Multimedia 2 students had an Instagram class account, namely (a)onebee.multimedia2. It had 56 followers and it followed 25 users who are the teacher and members of Multimedia 2. The account is presented in Figure 3. 
EduLite Journal of English Education, Literature, and Culture Vol. 5, No. 2, August 2020, pp. 240-250

E-ISSN: 2528-4479, P-ISSN: 2477-5304 http://jurnal.unissula.ac.id/index.php/edulite DOI: http://dx.doi.org/10.30659/e.5.2. 240-250

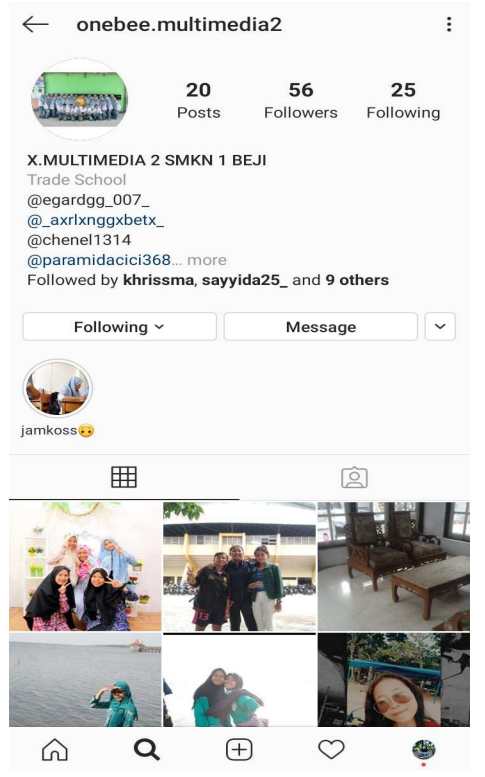

Figure 3. Instagram class account of Multimedia 2
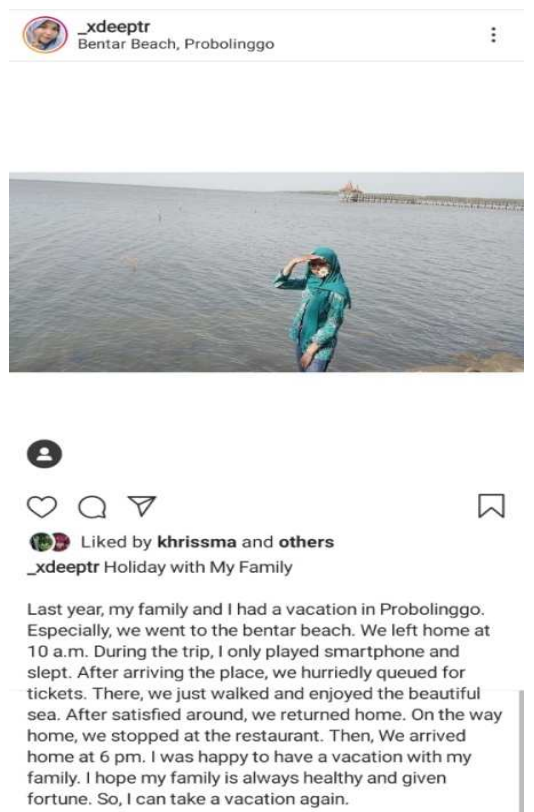

Figure 4. One of the students' recount texts in Instagram

mauliya.avivi Dea, please give title on your writing. Well, it still needs more sentences to make it better to read. Keep spirit.

Figure 5. The feedback from the teacher

The result of the students' writing showed that the mean score of Multimedia 2 class (experimental group) was 75.73, and the mean score of Multimedia 1 class (control class) was 66.33. Further, the normality test was identified that the value of observed $\mathrm{D}<$ Kolmogorov-Smirnov table. It means that the data of pre-test and post-test of experimental and control class have 
normal distribution. Next, the homogeneity test showed that the value of observed $\mathrm{F}(1.04)<\mathrm{F}_{\text {table }}(1.88)$, and it indicates that the data of pre-test is homogeneous. In addition, the data of post-test is homogeneous through the result showing the value of observed $\mathrm{F}(1.56)<\mathrm{F}_{\text {table }}(1.88)$.

After identifying that the data have met the fulfilment of statistical assumption, parametric test was used. The calculation of Independent sample $t$-test showed that observed $t$ value $(3.70)>t_{\text {table }}(2.30)$. It means that the value of observed $t$ is higher than $t_{\text {table }}$ with a 0.05 (95\% significant level). Thus, it reveals that null hypothesis $\left(\mathrm{H}_{\mathrm{o}}\right)$ is rejected. In other words, there is significant effect of Instagram caption through process approach to the students in writing recount text.

\section{Discussion}

The learning outcomes from the use of Instagram through process approach show positive results. This is in line with the result of the previous studies (Mursela, 2018; Triwinarsih, 2019; Anggia, 2019). Additionally, Instagram can be as a way for students to learn writing and publish their learning output. It is supported with process approach in implementing Instagram as a media for writing recount text. The process approach is helpful for guiding students in writing because it consists of several steps such as planning, drafting, editing, and final version. Nabhan (2019) also explained that this approach inclines to involve collaborative activity and promotes creativity in writing process.

Zárate \& Cisterna (2017) state that Instagram offers marvelous atmosphere for foreign language learners to produce writing, one of the examples is by uploading picture and adding a caption that contains several sentences to describe or comment on a post. Besides, Mansor \& Rahim (2017) underlined in their study that in learning activities, Instagram promotes relaxed and enjoyable feeling for students in doing writing task. They also said that by using Instagram, the students were able to have communicative and writing skill improvement. Instgaram could escalate students' motivation in English class, and it also enhances students' participation during the learning activities (Purnama, 2018).

Instagram is one kinds of web 2.0 tool that can be used as a media in English class. However, there are other media that can be used for writing recount text includes blog and facebook. Putra et al. (2018) states that blog is an online tool for communicating with other people by posting texts and comments. It also has several features which make the students develop their creativity skill with blogging. Then, Irmawati (2019) argued that facebook is a social media that make students are motivated to use the features and publish the final writing in the wall application.

In addition, during implementing Instagram in this research, the researchers found some shortcomings such as time management and internet connection. Firstly, the time is quite limited because the students were given a half of treatment after doing the pre-test. The learning time has ended when the students had to post their writing in Instagram. Thus, the students can post it outside class hours such as during take a rest or after school activities (at home). Secondly, sometimes the internet connection is lost because the 
new class that they were using is a little far from where the internet connection is. Therefore, the teacher should have requested additional access for the English class or students could share internet connection via hotspot on their mobile phone.

\section{CONCLUSION}

Based on the result of data that has been analyzed by the researchers, using Instagram caption through process approach gives a positive effect in learning writing recount text. The researchers also can state that using Instagram caption is an effective way for students to learn writing recount text and develops the students' writing. The use of Instagram is also supported with process approach for guiding the students' in generating ideas until publishing their writing.

Therefore, the result of this study contributes to the development of body knowledge related to instructional media for learning English by giving empirical evidence toward the strength of Instagram with process approach. Practically, the English teachers can be more creative in accommodating students' need for achieving learning outcomes. Understanding popular social media is one of the ways to attract students' learning interest. With careful procedure and sufficient supporting facilities, the better result may be obtained.

Since this study is restricted to Instagram caption, this study can be a recommendation for the next researchers who want to conduct research similar with this topic. Moreover, the next researchers are advised to investigate other strategy of Instagram use that has not been discussed. Exploring another potential feature of Instagram, levels of the participant, different writing approach, and research method are also opportunities for the future research.

\section{ACKNOWLEDGEMENTS}

The researchers would like to deliver thankful to Multimedia students and English teacher for supporting the process of collecting data to complete this paper.

\section{REFERENCES}

Adula, H. S. (2018). The practice of process approach in writing classes: Grade eleven learners of Jimma preparatory and Jimma university community preparatory school in focus. International Journal of English and Literature, 9(5), 39-49. https://doi.org/10.5897/IJEL2018.1158

Alfiyatun. (2018). The effectiveness of instagram captions to teach writing. Undergraduate Thesis. Surakarta: The State Islamic Institute of Surakarta. 
Ali, S. A. (2014). Embracing the selfie craze: Exploring the possible use of Instagram as a language mLearning tool. Issues and Trends in Educational Technology, 2(2), 1-16. Retrieved from https://journals.uair.arizona.edu/index.php/itet/article/view/18274/18 $\underline{091}$

Anggia, I. S. (2019). The use of instagram post for assisting tenth graders in writing recount text. RETAIN, 7(2). Retrieved from https://jurnalmahasiswa.unesa.ac.id/index.php/retain/article/view/29 $\underline{081}$

Ary, D. J. \& Razavie. (2010). Introduction to research in education ( $8^{\text {th }}$ ed), United Stated: Waddsworth Cangange Learing.

Brown, H. D. (2004). Language Assessment: Principles and classroom practices. New York: Pearson Education.

Ferdig, R. E. (2007). Editorial: Examining social software in teacher education. Journal of Technology and Teacher Education, 15(1), 5-10. Retrieved from https://www.researchgate.net/publication/255566895_Editorial_Exami ning_Social_Software_in_Teacher_Education

Harmer, J. (2004). How to teach writing. England: Pearson Education Limited.

Irmawati, D. K. (2019). How to make use of facebook to write descriptive text?. Journal of English Educators Society, 4(1), 53-60. http://doi.org/10.21070/jees.v4i1.2013

Kessler, G. (2013). Teaching ESL/EFL in a world of social media, mash-up, and hyper-collaboration. TESOL Journal, 4(4), 615-632. Retrieved from https://scholar.google.com/citations?user=k0NKv-OAAAAJ\&hl=en

Maharani, M. M. (2017). The application of indirect feedback to improve students' paragraph writing. Edulite: Journal of English Education, Literature, and Culture, 2(2), 389-404. http://dx.doi.org/10.30659/e.2.2.389-404

Mansor, N. \& Rahim, N. A. (2017). Instagram in ESL classroom. Man in India, 97(20), 107-114.

Mursela, F. (2018). The effect of peer feedback through instagram on students' writing recount text. Jakarta: Syarif Hidayatullah State Islamic University.

Musonera, E. (2018). Instagram: a photo sharing application. Journal of the International Academy for Case Studies, 24(4). Retrieved from https://www.abacademies.org/articles/instagram-a-photo-sharingapplication-7773.html

Nabhan, S. (2016). The process approach to improve students' writing ability in English education department university of PGRI Adi Buana Surabaya. Jurnal Pengajaran Bahasa dan Sastra, 13, 1-12. Retrieved from https://www.researchgate.net/publication/316823668_THE_PROCESS APPROACH_TO_IMPROVE_STUDENTS\%27_WRITING_ABILITY_IN_ENGLI SH_EDUCATION_DEPARTMENT_UNIVERSITY_OF_PGRI_ADI_BUANA_SU $\underline{\text { RABAYA }}$ 
Nabhan, S. (2019). Bringing multiliteracies into process writing approach in ELT classroom: Implementation and reflection. Edulite: Journal of English Education, Literature, and Culture, 4(2), 156-170. http://dx.doi.org/10.30659/e.4.2.156-170

Purnama, A. D. (2018). Incorporating memes and instagram to enhance student's participation. Language and Language Teaching Journal, 21(1), 94-103. http://dx.doi.org/10.24071/LLT.2017.200101

Putra, F. Megawati, F. Astutik, Y. Mandarani, V. Novita, D. Taufiq, W. \& Santoso, D. (2018). Blogging: Writing in English with fun activities. Annual Conference on Social Sciences and Humanities (ANCOSH). Sidoarjo: Universitas Muhammadiyah Sidoarjo.

Sheldon, P. \& Bryant, K. (2016). Instagram: Motives for its use and relationship to narcissism and contextual age. Computers in Human Behavior, 58, 89-97. http://dx.doi.org/10.1016/j.chb.2015.12.059

Tribble, C. (1996). Writing. Oxford: Oxford University Press.

Triwinarsih, L. H. (2019). The efectiveness of using instagram to teach writing skill in recount text at the eighth grade of MTSN 02 Boyolali in the academic year 2018/2019. Undegraduate Thesis. Surakarta: The State Islamic Institute of Surakarta.

Zárate, P. \& Cisterna, C. (2017). Action research the use of instagram as an interactive tool for developing the writing of short stories. European Journal of Education Studies, 3(10), 527-543.

https://doi.org/10.5281/zenodo. 1035497 